\title{
Universiteit
}

Leiden

The Netherlands

\section{The problems of adverbs in Zulu}

Cheng, L.L.; Downing, L.J.; Caspers, J.; Chen, Y.; Heeren, W.F.L.; Pacilly, J.J.A.; ... ; Zanten, E.A. van

\section{Citation}

Cheng, L. L., \& Downing, L. J. (2014). The problems of adverbs in Zulu. In J. Caspers, Y. Chen, W. F. L. Heeren, J. J. A. Pacilly, N. O. Schiller, \& E. A. van Zanten (Eds.), Above and beyond the segments: experimental linguistics and phonetics (pp. 42-59). Amsterdam: John Benjamins. doi:10.1075/z.189.04che

Version: $\quad$ Publisher's Version

License:

Licensed under Article 25fa Copyright Act/Law (Amendment Taverne)

Downloaded from: https://hdl.handle.net/1887/3245242

Note: To cite this publication please use the final published version (if applicable). 


\title{
The problems of adverbs in Zulu*
}

\author{
Lisa Lai-Shen Cheng and Laura J. Downing
}

Adverbs in Durban Zulu appear to have contradictory properties. On the one hand, when they appear with intransitive verbs, they phrase prosodically with the verb, just like direct objects. On the other hand, adverbs which appear with transitive verbs are like typical adjuncts, which are adjoined above $\nu \mathrm{P}$, and they are prosodically phrased separately from the rest of the sentence. We suggest that due to the nominal character of adverbs in Zulu, they can be selected by the verb. Selected materials (including selected adverbs) are merged at the time of main structure building, while non-selected adverbs and other adjuncts are merged late. The timing of the merger of adverbs reflects their prosodic phrasing properties.

\section{Introduction}

This paper examines the syntactic and prosodic properties of adjuncts (adverbs as well as adjunct clauses) in Durban Zulu. Previous work by Cheng \& Downing (2012) suggests that adjuncts are adjoined above $\nu \mathrm{P}$, and they are phrased separately from the rest of the sentence (to satisfy general prosodic phrasing constraints). However, adverbs which appear with intransitive verbs behave as if they are part of the verb phrase (i.e., they behave like a regular direct object); thus they also prosodically phrase with the verbs. Furthermore, focused adverbs behave like typical focused elements in that: (a) they appear immediately after the verb; (b) they appear with conjoint verb forms; and (c) prosodically, they phrase with the verb.

In other words, adverbs in particular appear to have contradictory properties. We discuss these properties in detail below. We propose an analysis which takes advantage of the nominal character of adverbs, as well as non-standard structure building for adjuncts.

* We thank Meritta Xaba, our language consultant, for her patience in going over the Zulu sentences with us. Unless indicated otherwise, all the Zulu data in this paper come from elicitation work with Meritta Xaba, a native speaker of Durban Zulu. 


\section{Preliminaries}

Canonical word order in Bantu languages is S V IO O (Bearth, 2003) and most adverbs follow the objects. This is also the case in Durban Zulu. Furthermore, in Zulu prosodic phrasing is marked by lengthening the phrase penult vowel. (Note that vowel length is not contrastive.) The data in (1) illustrates the canonical word order, as well as the fact that in neutral contexts (including broad focus contexts), the whole sentence (including direct and indirect object) is parsed into one prosodic phrase. (Parentheses indicate prosodic phrasing throughout the paper.)

(1) Zulu (Cheng \& Downing, 2007, 2009)
a. (Bá-níké ú-Síphó í-ma:li)
2suBJ-give.TAM 1-Sipho 9-money
'They gave Sipho money.'
b. (Ú-Síph' ú-phékél' ú-Thánd' in-kú:khu)
1-Sipho 1subJ-cooked.for 1-Thandi 9-chicken
'Sipho cooked chicken for Thandi.'

Cheng \& Downing (2012) show that in broad focus and VP focus contexts, adverbs are phrased separately from the objects, as in (2).

(2) Zulu (Cheng \& Downing, 2012)
a. Q What did Sipho do?
A ((Ú-Síph’ ú-phék' ín-ku:khu) kwám’ ízo:lo) VP focus
1-Sipho 1subJ-cook 9-chicken 17-1sg yesterday
'Sipho cooked chicken at my place yesterday'.
b. Q What happened?
A ((Bá-ník' ú-Síph' í-bhayiséki:li) namhlá:nje) broad focus 2suBj-gave 1-Sipho 5-bicycle today 'They gave Sipho a bicycle today'.

\section{Focus and IAV}

Focused constituents (e.g., wh-phrases) in Zulu must appear immediately after the verb, and be prosodically phrased together with the verb. Furthermore, non-focused objects, which must be dislocated, are associated with an obligatory object marker (bolded) (see Buell, 2009; Cheng \& Downing, 2012). In (3a,b), we see that the nonfocused indirect object is associated with the object marker $m$.
(3) a. Q. (Bá-m-níké:-ni) (ú-Sí:phó)
2subJ-1овJ-give-what 1-Sipho
'What did they give to Sipho?'
b. A. (Bá-m-níké: í-ma:li) (ú-Sí:pho)
2subJ-1obJ-give 9-money 1-Sipho
'They gave money to Sipho.'


Note that the dislocated objects are prosodically phrased separately from the rest of the sentence.

\section{Conjoint-disjoint verb forms}

Zulu also has the so-called conjoint-disjoint verb forms (see Creissels, 1996). The disjoint forms for Zulu are the prefix -ya-in the present tense and the suffix -ile in the recent past. The disjoint form (as shown in (4a) and (5a)) must appear clause finally. In contrast, the conjoint form cannot appear clause finally, as shown in (4b) and (5b). (See Van der Spuy, 1993; Buell, 2006; data below adapted from Buell, Cheng \& Schadeberg, in prep.)
(4) a. (Ngi-ya-cu:l-a)
(disjoint)
$\left({ }^{\star}\right.$ Ngi-cula. $)$
1s.SM-DJ-sing-FV
'I'm singing.'
b. (Ngi-cul-a íngo:ma) (conjoint)
1s.SM-DJ-sing-FV 9song
'I'm singing a song.'
(5) a. (Ngi-cul-i:le.)
(disjoint) $\quad\left({ }^{\star N g i-c u l-e .)}\right.$
1s.SM-sing-DJ.TAM
'I sang.'
b. (Ngi-cul-ê íngo:ma) (conjoint)
1s.sM-sing-TAM 9song
'I sang a song.'

Furthermore, as we can see in these examples, with the conjoint form the object following the verb is prosodically phrased together with the verb.

\section{Relative clauses (Cheng \& Downing, 2007)}

Further evidence for the syntactic factors that determine prosodic phrasing comes from comparing restrictive and appositive relative clauses. As we can see in the examples below, the right edge of a restrictive relative clause determines a prosodic break, while the left edge does not:
(6) a. (( $\left[_{T P}\left[{ }_{D P}\left[{ }_{C P} I ́ n-d o d ’ e ́-g q o k e ̂ \quad\right.\right.\right.$ ísí-gqooko $\left.\left.]\right]\right)$ í-boné ízi-vakááshi $\left.]\right)$ 9-man REL.9subJ-wear 7-hat 9subJ-see 8-visitor 'The man who is wearing a hat saw the visitors.'
b. (Si-phul' ${ }_{D \mathrm{DP}}\left[_{\mathrm{CP}}\right.$ ím-baz' é-théngwê námhláánje]]) we-break 9-axe REL9subJ-buy.PAss.TAM today 'We broke [the axe that has been bought today].'

Appositive (non-restrictive) relatives, in contrast, allows both edges to determine a prosodic break: 
(7) a. ${ }_{D P}{ }_{D P}(U ́$-nhla:nhlá) $]\left[{ }_{C P}\right.$ (ó-thénge ámá-tha:ngá) $\left.]\right]$ ú-wá-thwéle 1-Nhlanhla REL1-buy 6-pumpkin SM1-om6-carry ngó-bhasikí:di)

withla-basket

'Nhlanhla, who bought the pumpkins, is carrying them in a basket.'

b. (si-mem' ${ }_{D P}\left[{ }_{D P}\right.$ ú-Ja:bu) ${ }_{[C P}(o-m$-ázi:-yo)] ] $\quad$ (é-dilîi:-ni) we-invite 1a-Jabu RELyou-OM1-know-REL LOC9-party-LOC 'We are inviting Jabu, who you know, to the party.'

\section{Adverbs in neutral contexts}

Single adverb

As Poulos \& Msimang (1998) show, the conjoint verb form is used if the verb is followed by an object (8a) or adverb (8b). (The data below is from Poulos \& Msimang, 1998, p. 266.)

(8) a. Izinja zi-lume i-kati (conjoint)

10.dog 10subJ-bit 5-cat

'The dogs bit the cat'

b. Umalume u-fike izolo (conjoint)

1a.uncle 1suBJ-arrive yesterday

'My maternal uncle arrived yesterday'.

Furthermore, in cases such as (8b), where there is no postverbal direct object, and no particular focus (and where the verb is in the conjoint form and followed by an adverb), the adverb prosodically phrases with the verb. (9)-(11) provide sentences with different types of adverbs, showing that an intransitive verb can be followed by various types of adverbs, which all trigger the conjoint form of the verb. They are all prosodically phrased with the verb.

(9) a. (ú-Si:phó) (ú-phéka ka:hle)

1-Sipho 1subJ-cook well

'Sipho cooks well.'

b. (ú-Si:phó) (ú-phéka kamná:ndi)

1-Sipho 1subJ-cook delicously

'Sipho cooks deliciously'

c. (ú-Sipho ú-phéké masínyá:ne / ngokúshe:sha)

1-Sipho 1suBJ-cook quickly/quickly

'Sipho cooked quickly.' 
(10) a. (ú-Sípho ú-fíké ngesítíme:la)

1-Sipho 1subJ-arrive by.train

'Sipho arrived by train.'

b. (ú-hámba ngóbho:ko)

1suBJ-walk with.stick

'He walks with a stick.'

(11) a. (ú-lálé pha:nsi)

1-slept on.floor

'He slept on the floor.'

b. (ú-Síphó ú-fíké ízo:lo)

1-Sipho 1subJ-arrive yesterday

'Sipho arrived yesterday.'

If the verb is in the disjoint form when followed by an adverb, then the adverb prosodically phrases separately from the verb, and the verb can be interpreted as focused.
a. ((ú-Sipho ú-phék-i:le) ngokúshe:sha)
1-Sipho 1suBJ-cook.DJ.TAM quickly
'Sipho DID cook quickly'.
b. ((ú-yá-há:mba) ngóbho:ko) (úmá úm-le:nze ú-m-hlú:pha) 1suBJ-DJ-walk with.cane if 3-leg 3suBj-10M-afflict 'He wALKs with a cane if his leg bothers him.'

If there is an object plus an adverb following the verb, however, the object is phrased with the verb (conjoint), while the adverb is prosodically phrased separately.
a. (ú-Si:pho) ((ú-fúndê í-ncwa:di) ngóbúci:ko)
1-Sipho 1subJ-read 9-book carefully
'Sipho read the book carefully.'
b. (ú-Si:pho) ((úphéké í-só:bho) kamná:ndi)
1-Sipho 1subJ-cooked 5-soup deliciously
'Sipho cooked the soup deliciously'.

\section{Multiple adverbs}

In cases where intransitive verbs are followed by two adverbs, the first adverb is combined with the verb just like in single adverb cases: the verb has conjoint form, and the adverb is prosodically phrased together with the verb. The second adverb is then phrased separately. In (14), different combinations of adverbs are shown, and they all yield the same pattern. 
(14)
a. ((ú-phékê ka:hle) ízo:lo)
1suBJ-cooked well yesterday
'He cooked well yesterday'
b. (ú-Thá:ndi) ((úhámbê: étótó:ba) ngóbho:ko)
1-Thandi walked slowly with.stick
'Thandi walked slowly with a walking stick.'
c. (((ú-hámbê: ngóbho:ko) ízo:l') ébúsu:ku)
1suBJ-walked with.stick yesterday night
'S/he walked with a walking stick last night.
d. ((ú-lálé pha:nsi) ízo:lo)
1suBj-slept on.floor yesterday
'He slept on the floor yesterday.'

When there is an object present, the pattern is similar to that found when a single adverb follows a transitive verb: the verb has conjoint verb form, and it phrases with the object. The verb and object combination is then phrased separately from the adverbs. What is interesting is that the first adverb is also phrased separately from the second adverb, as shown in $(15 a, b)$.
a. (((ú-phúze í-kho:fi) ngéndí:shi) fu:thi)
1suBJ-drank 5-coffee with.bowl again
'He drank coffee with a bowl again.'
b. ((((ú-Sipho ú-sík-él-ê ú-Tha:ndí) í-phê:phá) ngobúcî:ko) 1-Sipho 1sUBJ-CUT-APPL-TN 1-Thandi 5-paper carefully ízo:lo) yesterday

'Sipho cut the paper for Thandi carefully yesterday'

The pattern in which adverbs are phrased separately from each other is also found when there are three adverbs:

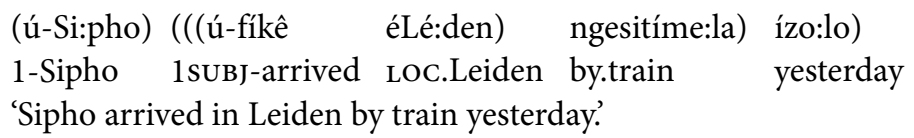

\section{Ordering between the adverbs}

Zulu postverbal adverbs obey ordering restrictions, and these are essentially what we anticipate: manner and location adverbs precede temporal adverbs. Crucially, temporal adverbs appear to be the most peripheral ones, while manner and location adverbs, for instance, have more flexibility among each other. 
(17) a. ((ú-phéké kámnán:di) ízo:lo)

1suBJ-cooked deliciously yesterday

'He cooked deliciously yesterday'.

b. * upheke ízolo kamnandi

(18)

a. ((ú-lálé pha:nsi) ízo:lo)

1sUBJ-slept on.floor yesterday

'He slept on the floor yesterday.'

b. *úlálé izolo phansi

(19)

a. (ú-Thá:ndi) ((ú-hámbê: étótó:ba) ngóbho:ko)

1-Thandi 1suBJ-walked slowly with.stick

'Thandi walked slowly with a walking stick.'

b. (ú-Thá:ndi) ((ú-hámbê: ngóbho:ko) étótó:ba)

(20)

a. (ú-Si:pho) ((ú-fíké ngesikhâ:thi) ésíkóle:ni)

1-Sipho 1subJ-arrived on.time school.LOC

'Sipho came to school on time.'

b. (ú-Si:pho) ((ú-fíké ésíkóle:ni) ngesikhâ:thi)

(21) a. (ú-Nhla:nhla) ((ú-ngecibhizé ngamábó:mu) ó-nyáw-e:ni)

1-Nhlanhla 1suBj-stepped deliberately foot-LOC

b. (ú-Nhla:nhla) ((úngecibhizé ó-nyáw-e:ni) ngamábó:mu)

'Nhlanhla deliberately stepped on my foot.'

(22)
a. (ú-Si:pho) (((ú-fíkê éLé:den) ngesitíme:la) ízo:lo)
1-Sipho 1subJ-arrive Leiden.LOC by.train yesterday
b. (ú-Si:pho) (((úfíkê ngesitíme:la) éLé:den) ízo:lo)
c. (ízo:lo) (ú-Si:pho) ((úfíkê ngesitíme:la) éLé:den)
d. ${ }^{*}$ uSipho ufike izolo eLeden ngesitimela
e. *uSipho ufike eLeden izolo ngesitimela
'Sipho arrived in Leiden by train yesterday'.

In sum, we have seen that a single postverbal adverb in Zulu can be treated on a par with the object in terms of conjoint verb form and prosodic phrasing when no object is present. If an object is present, adverbs are outside the verb-object combination, and they are also prosodically phrased separately from each other. Before we discuss plausible treatments of Zulu adverbs, it is necessary to first understand our basic assumptions about prosodic phrasing in Zulu. 


\section{Prosodic phrasing in Zulu}

Cheng \& Downing $(2009,2012)$ show that the right edge of $v$ P and CP phases in Zulu systematically correlates with a prosodic phrase break. Since it is only the right edge of the $v \mathrm{P}$ and $\mathrm{CP}$ phases that can determine a prosodic phrase break, in sentences such as $(23 \mathrm{a}, \mathrm{b})$, the whole sentence is one prosodic phrase.
a. ([ [ úm-fúndísi ú-fúndel-ê: ábá-zal' ín-cwa:di])
1-teacher 1-read to-TAM 2-parent 9-letter
'The teacher read to the parents a letter'.
b. ([CPú-Síph' ú-fún’ [CPúkúth' ú-Thándi á-théng’ í-bhayiséki:li]]) 1-Sipho 1-want that 1-Thandi 1-buy 5-bicycle

'Sipho wants Thandi to buy a bicycle.'
c. ((Bá-ník’ ú-Síph' í-bhayiséki:li) namhlá:nje) broad focus
2subJ-gave 1-Sipho 5-bicycle today

'They gave Sipho a bicycle today'
d. (([CP [CP Ín-dod’é-gqoke ísí-gqo:ko]) í-bon-é ízi-vaká:shi] $)$ 9-man REL.9-wear 7-hat 9-see-TAM 8-visitor

'The man who is wearing a hat saw the visitors.'

e. ([ ${ }_{C P} \mathrm{si}$-phul' [ ${ }_{C P}$ ím-baz' é-théngw-é námhlâ:nje $\left.\left.]\right]\right)$ we-break 9-axe REL.9-be.bought-TAM today 'We broke the axe that has been bought today.'

(23d,e) involve restrictive relative clauses. In (23d), the right edge of the relative CP yields a prosodic break. On the other hand, in (23e), since the left ledge of a relative $\mathrm{CP}$ does not play any role in prosodic phrasing, it does not lead to a prosodic break. In the case of (23c), since the adverb is phrased separately from the object, we can conclude that it is adjoined above the $v \mathrm{P}$.

The prosodic phrasing algorithm is formalized in a phase sensitive Edge-based analysis with the following constraints (Cheng \& Downing, 2009, 2012):
a. AlignR[Phase, IntPh] (AlignR-Phase)
Align the right edge of every phase $(\nu \mathrm{P} / \mathrm{CP})$ with the right edge of an Intonation Phrase (IntPh).
b. AlignR[IntPh, Phase] (AlignR-IntPh)
Align the right edge of every Intonation Phrase (IntPh) with the right edge of a phase $(v \mathrm{P} / \mathrm{CP})$.

The data that we have seen up to now also show that subjects in Zulu are optionally phrased separately from the verb. Cheng \& Downing $(2009,2012)$ show that the prosodic phrasing property of subjects is related to whether or not the subject is a topic. A topicalized subject is similar to a dislocated element; it phrases separately from the rest of the sentence. 


\section{Focus and adverbs}

We have seen above that in neutral contexts, or broad/VP focus contexts, adverbs are phrased separately from the verb phrase (verb-object complex), if an object is present. In this section, we discuss data with focused adverbs, where adverbs either carry new information focus or contrastive focus. In such cases, the adverbs behave the same way as focused arguments: they are immediately after the verb, and non-focused objects are dislocated, with obligatory object marking in the verb component.

Recall from Section 2 above that in canonical word order adverbs follow the verb and any objects, and temporal adverbs, in particular, appear in the periphery (either left or right). Consider first the sentences in (25)-(28). They show that when adverbs are focused, the word order is changed.
a. (((ú-hámbê: ngóbho:ko) ízo:l') ébúsu:ku)
1suB-walked with.stick yesterday night
'S/he walked/left with a walking stick last night.'
b. (((ú-hámbê: ízo:l’) ébúsu:ku) ngóbho:ko)
1suBj-left yesterday night with.stick

- OK in answering the question: 'When did s/he leave and how?'

(26) Q: ((ú-lálé ni:ni) pha:nsi)

1suB-slept when on.floor

'When did s/he sleep on the floor?'

A: ((ú-lálé ízo:lo) pha:nsi) (compare with (14d) \& (18a,b))

1sUBJ-slept yesterday.on.floor

*ulale phansi izolo

(27)

a. ((ú-lí-phéké

kánja:n’) í-só:bh’)

(compare with (13b))

1suвJ-50M-cooked how 5-soup

'How did s/he cook the soup?'

b. * upheke isobho kanjani

(28)

((U-wa-thwéle ngáan’) amá-thaanga)

2suBJ-6om-carry how 6-pumpkin

'How are you carrying the pumpkins?'

(25a) illustrates the neutral, canonical word order, where the first adverb is phrased with the verb, and the second adverb is phrased separately. In this sentence, the temporal adverb follows the manner adverb. In contrast, in answering the question ' when did s/he leave and how, the temporal adverb is the new information focus, which appears immediately after the verb, just like other focused elements (see (3a,b) above), and the manner adverb ends up following the temporal adverb, yielding a word order that is different from the canonical word order. (26a,b) provides a similar pattern with location adverbs and temporal adverbs. 
(27) and (28) provide data with a direct object and a wh-adverbial. Wh-phrases are focused elements, and thus they appear immediately after the verb. The direct objects, which in canonical order directly follow the verb, need to be dislocated (in these cases, right-dislocated) and their corresponding object markers obligatorily appear in the verbal component.

The above examples show that focused adverbs are the same as focused arguments: they appear immediately after the verb, and they are prosodically phrased with the verb. If there is an object, the non-focused object must be dislocated. Note that a dislocated object precedes non-focused adverbs, as in (29)-(30).
a. (((ú-Síph’ ú-m-phékélê:-n’)
ú-Thâ:ndi) émzini
wakh'
1-Sipho 1suBJ-1овJ-cook.for-what 1-Thandi Loc.3.home 3.your ízo:lo)
yesterday
'What did Sipho cook for Thandi at your house yesterday?'

b. Q. Who did Sipho cook chicken for yesterday?
A. (((ú-Síph' ú-yí-phékélé
ú-Tha:nd') ín-ku:kh') ízo:lo)
1-Sipho 1suвJ-9овJ-cook.for 1-Thandi 9-chicken yesterday
'Sipho cooked chicken for Thandi yesterday'.

(30)
a. ${ }^{*}$ u-Sipho u-m-phekele-ni
emzin'
wakho izolo
1-Sipho 1subJ-1овJ-cook.for-what Loc.3.home 3.your yesterday
u-Thandi
1-Thandi
'What did Sipho cook for Thandi at your house yesterday?' (cf. (29a))
b. ${ }^{*}$ u-Sipho u-yi-phekele u-Thandi izolo ín-kukhu
1-Sipho 1subJ-9овJ-cook.for 1-Thandi yesterday 9-chicken
'Sipho cooked chicken for Thandi yesterday'. (cf. (29b))

In both (29a) and (29b), there are two objects. Since only one of the objects is focused, the other object has to be dislocated. In both cases, there are also adverbs present in the sentence, and the dislocated object needs to precede the adverbs. This can be seen from the ungrammatical sentences in $(30 \mathrm{a}, \mathrm{b})$, where the dislocated objects follow the verb.

\section{The syntax of IAV}

Buell (2009), Cheng \& Downing (2012), and Hyman \& Polinsky (2010) have shown that neither a high FocusP or a low FocusP can handle the immediately after the verb phenomenon in Bantu languages. Assuming that the verb moves to a position higher than $v$ P, but lower than TP (see Julien, 2002, and Buell, 2005), a high FocusP (i.e., the FocusP is higher than TP) means that the focused element is not really "immediately" 
after the verb unless there is remnant movement of the XP hosting the verb (to a position immediately preceding the FocusP). However, such a structure yields the wrong prosodic phrasing. (See Cheng \& Downing, 2012 for details concerning Zulu.)

Furthermore, the most difficult aspect of the immediately after the verb phenomenon for either a high or low FocusP is the so-called "exiting effect": the non-focused/ given objects need to be dislocated, and the object marking appears obligatorily. Consider the sentences in (31).
a. ${ }^{\star B a-b h a k-a ~ k a n j a n i} i_{i}$ isi-nkwat ${ }_{\mathrm{i}}$ ? 2suBj-bake-Fv how 7-bread 2suвJ-7om-bake-Fv how 7-bread 'How do they bake bread?'
b. ba-si-bhak-a kanjani isi-nkwa

(Buell, 2009)

(31a) shows that the "immediately after the verb" effect is not simply moving a focused element, crossing over the object: kanjani 'how' is an adverb, so its canonical position follows the object isinkwa 'bread'. In (31b), an object marker corresponding with the "exited object" appears, and the sentence is grammatical.

\section{The conjoint-disjoint distinction}

Van der Spuy (1993) and Buell (2005) argue for a correlation between conjoint/ disjoint forms and syntactic constituency. In particular, disjoint forms indicate that the verb is constituent final. In Buell (2005), the constituent is considered to be AgrSP.We follow Halpert (2012) in assuming that the conjoint form is used when $v \mathrm{P}$ contains material (though we do not follow Halpert's particular licensing analysis of the conjoint-disjoint distinction). Consider now the sentences in (32), where (32a) is similar to what we have seen above: nothing follows the verb, thus, the disjoint form is used.
a. aba-fana ba-ya-cul-a 2-boy 2subJ-DISJ-sing-FV
'The boys are singing.'
b. ku-cul-a aba-fana
17.sUBJ-sing-FV 2-boy
'The вочs are singing./There are boys singing.'
c. ba-ya-cul-a aba-fana
2sUBJ-DISJ-FV 2-boy
'They are singing, the boys.'
d. ${ }^{*}$ ku-ya-cul-a aba-fana
17suBJ-DISJ-sing-Fv 2-boy


(32b) is a sentence with class 17 subject agreement, which can be considered to be a default agreement, i.e., when the verb fails to agree with the subject (in this case, abafana '(the) boys'). Note that the verb in this case is in the conjoint form, suggesting that the subject noun phrase stays within the verb phrase. Its failure to move to the surface subject position (i.e., SpecTP) leads to the default agreement. Note that in this case, the verb has the conjoint form, indicating that the subject is inside the $v \mathrm{P}$. This contrasts with (32c), where we also see a postverbal subject. However, in this case, the verb agrees with the subject noun phrase, and the verb is in the disjoint form. The pattern in (32c) can be explained as follows: (a) the subject has first moved to SpecTP, triggering subject agreement; and (b) the subject is subsequently right-dislocated. In other words, in this sentence, the noun phrase abafana '(the) boys' is not in the verb phrase, but is outside of the AgrSP (or TP). In other words, the conjoint-disjoint forms of the verb allow us to diagnose whether a postverbal element is inside the $\nu \mathrm{P}$ or not.

The data in $(33 \mathrm{a}, \mathrm{b})$ provide further illustration. In these two sentences, there is a direct object following the verb. However, the verb is in disjoint form. This means that the object is not in the verb phrase; instead, it is right-dislocated. In (33a), the object is resumed by the corresponding object marker in the verbal component. In contrast, (33b) is ungrammatical because the verb is in disjoint form, indicating that the object is outside of the verb phrase; however, no object marker is present in the verbal component.
2-boy 2sUBJ-DISJ-9om-sing-FV 9-song
'The boys are singing a song.'
a. aba-fana ba-ya-yi-cul-a i-ngoma
b. *aba-fana ba-ya-cul-a i -ngoma
2-boy 2suBJ-DISJ-sing-FV 9-song

\section{Towards an analysis}

We have seen above that the prosodic phrasing properties of adverbs vary depending on whether an object is present and whether the adverbs are focused or not. Consider first the "canonical" cases where an object is present: adverbs are phrased separately from an object, and from each other. Traditional analyses of adverbs would adjoin adverbs to various syntactic phrases. In the case of Zulu, if we follow Cheng \& Downing $(2009,2012)$ in assuming that only the right edge of $\nu \mathrm{P}$ and $\mathrm{CP}$ phases determine the boundaries of prosodic phrases, then we have to adjoin adverbs either $\nu \mathrm{P}$ or $\mathrm{CP}$, as in (34). 
(34)

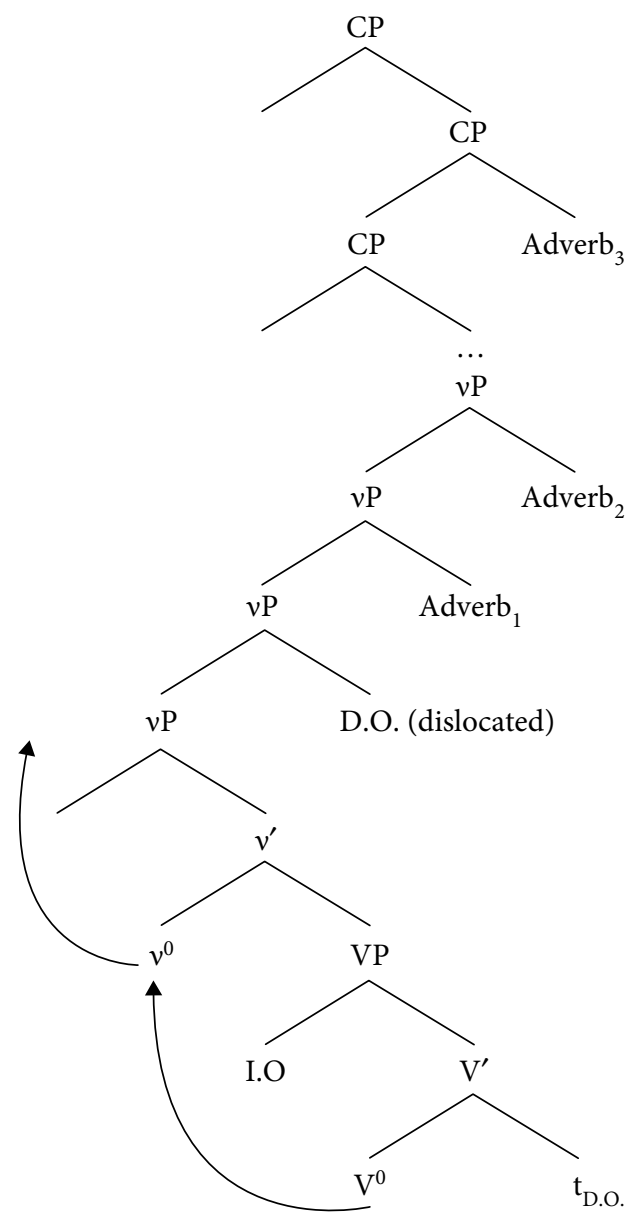

This on the surface can take care of canonical cases of non-focused adverbs (following a direct object). However, there are a number of problems if we take this route. First, adverbs such as temporal adverbs will have to be adjoined to $\mathrm{CP}$, which seems to be quite high for a temporal adverb, especially since temporal adverbs can interact with Tense to determine the interpretation of Tense, which is within the TP. Second, a rightdislocated object needs to precede all adverbs. If dislocation is a movement operation, it is unclear how we can ensure that the dislocated element is adjoined lower than all the adverbs. Lastly, if we were to take into consideration other adjuncts, such as nonrestrictive relative clauses like (7b), where both edges of the relative clause appear to play a role in determining prosodic phrasing, ${ }^{1}$ it is unclear how these results can be achieved in a uniform way.

1. Note that even if DP is a phase, it apparently does not determine a prosodic boundary in Zulu since Zulu noun phrases are not automatically phrased separately from other elements. 
In Cheng \& Downing (to appear), it is suggested that non-restrictive relative clauses are built on a different plane from the main plane/structure and they are merged late with the main structure (see also Bobaljik, 1999, and Chomsky, 2004). Further, materials on a different plane are not incorporated into the main plane prosody until late. This not only takes care of non-restrictive relative clauses (e.g., (7b)) but also adjunct clauses (as in $(35 \mathrm{a}, \mathrm{b})$, which are also phrased separately from the main clause:

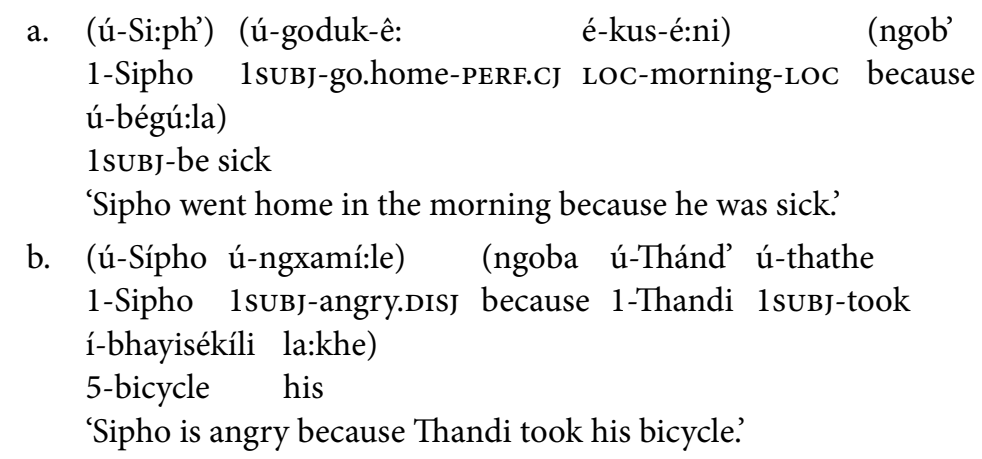

In other words, in both non-restrictive relative clauses and adjunct clauses, the left edge also matters for prosody. Note that adjunct clauses are not "automatically" grouped with intransitive verbs in that they do not trigger the conjoint form of the verb, as we can see in (35b).

However, adverbs cannot be treated straightforwardly on a par with non-restrictive relative clauses and adjunct clauses, because: (a) they are not always phrased separately from the verb; (b) they can trigger conjoint verb forms: i.e., they can be inside the $v P$; and (c) they also follow certain word order restrictions (especially temporal adverbs).

Adverbs following conjoint verbs

Consider now adverbs which follow intransitive verbs. What we need to account for is the fact that in such cases, adverbs are on a par with noun phrase complements. To understand this property of adverbs, it is important to know that adverbs in Zulu are mostly constructed based on nouns and pronouns (see Doke, 1927; Poulos \& Msimang, 1998; Halpert, 2012, among others). (36a,b) provide some examples.

(36) a. Adverbs formed by nga- (e.g., instrumental)

nga + imoto $\rightarrow$ ngemoto 'by car'

$n g a+$ intokozo $\rightarrow$ ngentokozo 'gladly, with joy'

b. Adverbs formed with $k a$ (to form temporal adverbs)

$k a+$ iningi $\rightarrow$ kaningi 'often; $k a+$ 'majority'

$k a+$ thathu $\rightarrow$ kathathu 'three times; $k a+$ 'three" 
Assuming that adverbs also have nominal features, we suggest that verbs in Zulu have a nominal feature to check (when the verb is not focused). Both typical nouns and "adverbial nouns" can check the nominal feature of the verb. Furthermore, we assume that conjoint verb forms are the "default" form. That is, unless a verb is $v \mathrm{P}$ final (which yields a disjoint form), the verb always has the conjoint form. (See Halpert, 2012 for a different analysis.)

Adverbs, just like nouns, can be selected to check the nominal feature of the verb; noun phrases on the other hand can also check theta-features of the verb as well. This naturally accounts for the similar distribution of adverbs and nouns in sentences like (37).
a. Ngì-cùl-à íngò:mà (conjoint)
1s.SM-DJ-sing-FV9 song
'I'm singing a song.'
b. ba-dlal-a phandle
2suBJ-play-Fv outside
'They're playing outside.'

(Buell, 2005)

However, in sentences like (37b), a nominal element cannot be selected because there is no theta-feature of the verb which can license a nominal. On the other hand, an adverb can check the nominal feature without having any theta-requirement. Given the fact that adverbs can be selected to check the nominal feature of the verb, we can conclude that adverbs can participate in the main plane/structure. In other words, adverbs are not entirely on a par with non-restrictive relative clauses or adjunct clauses, which are always merged late.

\section{Non-focused adverbs}

Now we turn to cases of transitive verbs (which take an object), where non-focused adverbs appear following objects. In this case, they are prosodically phrased separately from the verb and separately from each other. Furthermore, a (slight) ordering restriction holds amongst non-focused adverbs. We have stated in the beginning of Section 5 that a simple adjunction analysis will also not take care of the data that we have in Zulu (because of the ordering of the dislocated element and adverbs, as well as the fact that temporal adverbs cannot be adjoined to $\mathrm{CP}$ ).

We now explore an analysis where non-focused adverbs are merged late, similar to non-restrictive relative clauses and adjunct clauses. First, since adverbs are subject to an ordering restriction, we suggest that they are hierarchically arranged on a separate plane/structure: 
Adverbs are then merged late with the main structure/plane. The verb thus first combines with its object (because of its nominal feature and theta-requirement). As adverbs are merged late, we suggest that they do not get incorporated into the prosodic phrase with the verb and its object. Instead, they are recursively parsed into another prosodic phrase.

\section{Focused adverbs}

Let us now turn to focused adverbs, which "trigger" conjoint verb forms. In other words, focused adverbs are on a par with the other focused elements in not being merged late.

Cheng \& Downing (2012) propose that the constraints in (39) and (40) account for focus phrasing in Zulu:

(39) Highest Phrase Condition (HPC), adapted from Kratzer \& Selkirk (2007): Prominence [i.e., focus] is licensed within the highest phrase (HP) in the minimal $\nu \mathrm{P}$ phase. More precisely:

If prominent [focused], then in the Highest Phrase.

(40) Focus-Prominence Constraint (FPC; Samek-Lodovici, 2005):

Focused constituents must be assigned prosodic prominence (i.e., phrasal stress).

These two constraints work together to allow a single item in $v \mathrm{P}$ to be focused and, if there is a focused item, they allow only the focused item in $v$ P. We assume that focus adverbs have a focus feature, which can be selected by the verb (just like the nominal feature). Since they are "selected", they are merged in the main structure from the very beginning. In other words, selected materials are always merged in the main structure. This includes typical objects, focused adverbs and adverbs in the case of intransitive verbs.

\section{Conclusion}

We have shown in this paper that adjuncts in Zulu form a complex set of elements. In particular, adverbs do not always behave like adjuncts. They sometimes behave like nominal arguments. In particular, adverbs can behave like nominal arguments when an intransitive verb is present, and when they are focused (then they are like other focused elements).

We suggest that due to the nominal character of adverbs in Zulu, they can be selected by the verb (which must check its nominal feature). Furthermore, focused adverbs have a focus feature that must be checked.Verbs can thus select for adverbs to satisfy their nominal features and their focus features. 
Selected materials (including selected adverbs) are merged at the time of main structure building, and they are also incorporated into the prosodic phrasing of this main structure. On the other hand, non-selected adverbs and adjuncts (such as nonrestrictive relative clauses and adjunct clauses), are merged late - they can be considered to be material from another plane, which does not get incorporated into the main structure for prosodic phrasing, leading to the prosodic phrasing properties of nonselected adverbs and adjunct clauses: they are always prosodically phrased separately from the rest of the structure, and from each other.

\section{References}

Bearth, T. (2003). Syntax. In D. Nurse \& G. Philippson (Eds.), The Bantu languages (pp. 121-142). London: Routledge.

Bobaljik, J. (1999). Adverbs: The hierarchy paradox. Glot International 4.9/10, 27-28.

Buell, L. (2005). Issues in Zulu verbal morphosyntax. Unpublished PhD dissertation, University of California, Los Angeles.

Buell, L. (2006). The Zulu conjoint/disjoint verb alternation: Focus or constituency? ZAS Papers in Linguistics, 43, 9-30.

Buell, L. (2009). Evaluating the immediate postverbal position as a focus position in Zulu. Selected proceedings of ACAL 38. Somerville, MA: Cascadilla Press, 166-172.

Buell, L., Cheng, L. L.-S. \& Schadeberg, T. (in prep.). Word order and morphological marking in Bantu. Manuscript.

Cheng, L. L.-S., \& Downing, L. J. (2007). The phonology and syntax of relative clauses in Zulu. Bantu in Bloomsbury: Special issue on Bantu linguistics. SOAS WPL, 15, 51-63.

Cheng, L. L.-S., \& Downing, L. J. (2009). Where's the topic in Zulu? In H. de Hoop, \& G. van Bergen (Eds.), Special issue on topics cross-linguistically, The Linguistic Review, 26, 207-238. Cheng, L. L.-S., \& Downing, L. J. (2012). Against FocusP: arguments from Zulu. In I. Kucerova,

\& A. Neeleman (Eds.), Information structure: Contrasts and positions (pp. 247-266). Cambridge: Cambridge University Press. DOI: 10.1017/CBO9780511740084.012

Cheng, L. L.-S., \& Downing, L. J. (to appear). Phasal syntax = cyclic phonology? Syntax.

Chomsky, N. (2004). Beyond explanatory adequacy. In B. Adriana (Ed.), Structures and beyond:

The cartography of syntactic structure, Vol. 3 (pp. 104-131). Oxford: Oxford University Press.

Creissels, D. (1996). Conjunctive and disjunctive verb forms in Tswana. South African Journal of African Languages, 16, 109-115.

Doke, C. M. (1927). Textbook of Zulu grammar. Cape Town: Maskew Miller Longman.

Halpert, C. (2012). Argument licensing and agreement in Zulu. Unpublished $\mathrm{PhD}$ dissertation, MIT.

Hyman, L., \& Polinsky, M. (2010). Focus in Aghem. In M. Zimmermann, \& C. Féry (Eds.), Information structure: Theoretical, typological, and experimental perspectives (pp. 206-233). Oxford: Oxford University Press.

Julien, M. (2002). Syntactic heads and word formation. New York: Oxford University Press.

Kratzer, A., \& Selkirk, E. (2007). Phrase theory and prosodic spellout: the case of verbs. The Linguistic Review, 24, 93-135. DOI: 10.1515/TLR.2007.005 
Poulos, G., \& Msimang, C. T. (1998). A linguistic analysis of Zulu. Pretoria: Via Afrika.

Samek-Lodovici, V. (2005). Prosody-syntax interactions in the expression of focus. Natural Language and Linguistic Theory, 23, 687-755. DOI: 10.1007/s11049-004-2874-7

Van der Spuy, A. (1993). Dislocated noun phrases in Nguni. Lingua, 90, 335-355.

DOI: 10.1016/0024-3841(93)90031-Q 